\title{
Sulfur speciation in soured reservoirs: chemical equilibrium and kinetics
}

\author{
Mahsan Basafa ${ }^{1}$ (D) $\cdot$ Kelly Hawboldt ${ }^{1}$
}

Received: 11 August 2019 / Accepted: 23 December 2019 / Published online: 2 January 2020

(c) The Author(s) 2020

\begin{abstract}
Reservoir souring is a widespread phenomenon in reservoirs undergoing seawater injection. Sulfate in the injected seawater promotes the growth of sulfate-reducing bacteria (SRB) and archaea-generating hydrogen sulfide. However, as the reservoir fluid flows from injection well to topside facilities, reactions involving formation of different sulfur species with intermediate valence states such as elemental sulfur, sulfite, polysulfide ions, and polythionates can occur. A predictive reactive model was developed in this study to investigate the chemical reactivity of sulfur species and their partitioning behavior as a function of temperature, pressure, and $\mathrm{pH}$ in a seawater-flooded reservoir. The presence of sulfur species with different oxidation states impacts the amount and partitioning behavior of $\mathrm{H}_{2} \mathrm{~S}$ and, therefore, the extent of reservoir souring. The injected sulfate is reduced to $\mathrm{H}_{2} \mathrm{~S}$ microbially close to the injection well. The generated $\mathrm{H}_{2} \mathrm{~S}$ partitions between phases depending on temperature, pressure, and $\mathrm{pH}$. Without considering chemical reactivity and sulfur speciation, the gas phase under test separator

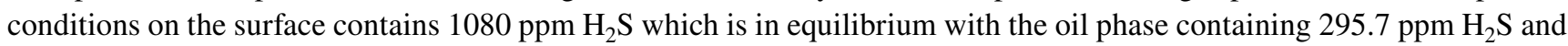
water phase with $\mathrm{H}_{2} \mathrm{~S}$ content of $8.8 \mathrm{ppm}$. These values are higher than those obtained based on reactivity analysis, where sulfur speciation and chemical reactions are included. Under these conditions, the $\mathrm{H}_{2} \mathrm{~S}$ content of the gas, oil, and aqueous phases are 487 ppm, 134 ppm, and 4 ppm, respectively.
\end{abstract}

Keywords Chemical reactivity $\cdot$ Seawater injection $\cdot$ Sulfur speciation $\cdot$ Reactive model

\section{Introduction}

The injection of sulfate-containing seawater into an oil reservoir, for either maintaining the reservoir pressure or as an enhanced oil recovery (EOR) method, promotes the activity of sulfate-reducing bacteria and archaea near the injection wells, leading to the formation of hydrogen sulfide $\left(\mathrm{H}_{2} \mathrm{~S}\right)$. The formation of hydrogen sulfide in originally sweet reservoirs is known as reservoir souring. The amount of hydrogen sulfide in the gas phase under test separator conditions is an indicator of the extent of souring. However, intermediate sulfur species with different valence states, between that of sulfate $(+6)$ and sulfide $(-2)$, such as polythionates and polysulfides, have been detected in several produced water samples, due to oil production methods and subsequent chemical and microbial reactions, and phase partitioning

Mahsan Basafa

mahsan.basafa@mun.ca

1 Faculty of Engineering and Applied Science, Memorial University of Newfoundland, St. John's, Canada
(Putra and Hakiki 2019; Veshareh and Ayatollahi 2019; Miranda-Trevino 2013; Yu et al. 2006; Antonio et al. 2000; Witter and Jones 1998; Boulegue et al. 1981).

The level and types of sulfur species (i.e., sulfur speciation) are a function of temperature, pressure, $\mathrm{pH}$, and composition. The intermediate sulfur species participate in various oxidation-reduction (redox) reactions. As conditions change within flowlines and unit operations, these species could degrade to corrosion causing and health and safety problematic compounds (Xu and Schoonen 1995; Xu et al. 2000; Druschel et al. 2003). The presence of reduced forms of sulfur impacts the bioavailability of toxic metals as complexation and precipitation of transition metals occur (Lewis 2010; Gramp et al. 2010; Witter and Jones 1998). The distribution of sulfur compounds is important to evaluate the effectiveness of souring mitigation options in either preventing the formation of sulfide or lowering the amount of sulfide already presents.

Microbial activity, thermochemical sulfate reduction, thermolysis of organosulfur compounds, and oxidative and reductive dissolution of metal sulfides impact sulfur 
production and speciation in the reservoir fluid. Previous studies of sulfur speciation have focused on sulfur chemistry in crude oils and asphaltenes (Pomerantz et al. 2013; Garcia et al. 2002). Sulfur is present in these organic phases in aliphatic chains, thiophenes, and sulfoxides. However, there is little study of sulfur speciation and chemical reactivity of inorganic sulfur compounds in reservoir fluids. The role of intermediate sulfur species in biological activity is well documented (e.g., Tang et al. 2009; Steudel 1996). However, there is a gap in knowledge in chemical reactivity of these inorganic sulfur species in seawater-flooded reservoirs. Therefore, identifying the reactivity and the partitioning behavior of these compounds is a critical step in developing souring control strategies.

The focus of this work is to investigate sulfur speciation as the reservoir fluid flows from injection to production in reservoirs undergoing seawater injection. As temperature and pressure change during production, sulfur species with different valence states are produced which impacts the $\mathrm{pH}$ of the environment, hydrogen sulfide concentration and distribution, and finally the extent of reservoir souring. A reactive model which includes both equilibrium and kinetic chemical reactions of sulfur species is developed to identify possible sulfur species of concern and predict relative sulfur speciation trend with changing temperature, pressure, and $\mathrm{pH}$.

\section{Methodology}

\section{Analysis of sulfur species reactivity}

The chemical composition of a multi-component reacting system is controlled by the type of the chemical interactions between substances. The equilibrium and kinetically controlled reactions are combined to give a complete picture of the reaction pathways. The kinetic reactions are modeled based on the principle of conservation of mass. This results in a system of partial differential equations (PDEs). The equilibrium reactions are modeled based on equilibrium expression governed by mass action equilibrium equations resulting in a system of nonlinear algebraic equations (AEs) (Yeh and Tripathy 1989; Yeh et al. 2001; Steefel et al. 2005; Berk et al. 2015).

The plug flow reactor model is used for studying the chemical reactivity of sulfur species in a sample reservoir fluid under steady-state conditions. Assuming that the fluid is perfectly mixed in the radial direction and the composition of the reacting system is controlled by convection, the mole balance for each component in a plug flow reactor model, considering constant velocity of the fluid, is given by the following differential equation (Froment et al. 2009): $u \frac{\mathrm{d}\left(C_{i}\right)}{\mathrm{d} z}=r_{i}$

where $u$ is the fluid velocity and $r_{i}$ is the rate of chemical reaction of species $i$.

Assuming that the sulfur reactions occur only in the aqueous phase, this equation leads to a system of ordinary differential equations for each species and can be solved numerically. The distance between injection and production is represented as a series of elements and within each element the temperature and pressure are varied. Concentration of each component is first calculated by solving the system of differential equations in the first element. However, not all reactions that could occur have published reaction rate equations; therefore, where there are reaction rate data gaps, it is assumed the reaction is governed by equilibrium. This enables one to include the desired compounds, present in the fluid, in the model. After the reaction rate equations are solved, the system of nonlinear algebraic equations obtained for equilibrium governed reactions is solved to get the final concentrations exiting the first element. The Gibbs reaction minimization method, summarized in the following section, is used for simulating the equilibrium reactions (Smith et al. 2005). The composition of the reacting system in the element is used as the input to the next element. The equilibrium and kinetic reactions are selected based on a comprehensive literature review followed by a screening study based on equilibrium analysis (Tables 1,2).

\section{Equilibrium analysis using Gibbs reaction minimization}

When two or more independent reactions proceed simultaneously, the equilibrium mole fractions of $\left(x_{i}\right)$ of the species present are related to the reaction coordinate $(\varepsilon)$ by (Smith et al. 2005):

$x_{i}=\frac{n_{i 0}+\sum_{j} v_{i, j} \varepsilon_{j}}{n_{0}+\sum_{j} v_{j} \varepsilon_{j}}$

where $\varepsilon_{j}$ applies to each reaction and $v_{i, j}$ designates the stoichiometric number of species $i$ in reaction $j$. Summation over all species yields: $v_{j}=\sum_{i} v_{i, j} . n_{i 0}$ is the initial concentration of species $i$ and $n_{0}$ is the initial concentration of the reacting system.

The uniformity of temperature, pressure and chemical potential of each component throughout all the coexisting phases at equilibrium leads to:

$\sum_{i} v_{i} \mu_{i}=0$

According to the definition of the fugacity of a species in solution: 
Table 1 Equilibrium reactions of sulfur-containing compounds considered in this study (Moses et al. 1987; Machel 1987; Zhang and Millero 1991, 1993; Heinen and Lauwers 1996; Wilkin and Barnes 1996; Lin et al. 2004; Zhao et al. 2007; TengShui et al. 2009; Zhang and Jeffrey 2010; Miranda-Trevino et al. 2013)

\begin{tabular}{|c|c|c|}
\hline & $\mathrm{pH}$ & Temperature $\left({ }^{\circ} \mathrm{C}\right)$ \\
\hline $\mathrm{H}_{2} \mathrm{~S} \leftrightarrow \mathrm{H}^{+}+\mathrm{HS}^{-}$ & $5-8$ & - \\
\hline $\mathrm{HS}^{-} \leftrightarrow \mathrm{H}^{+}+\mathrm{S}^{2-}$ & $>7$ & - \\
\hline $\mathrm{S}_{2} \mathrm{O}_{3}{ }^{2-}+\mathrm{H}_{2} \mathrm{O} \leftrightarrow \mathrm{H}_{2} \mathrm{~S}+\mathrm{SO}_{4}{ }^{2-}$ & 12 & $>70$ \\
\hline $\mathrm{S}_{2} \mathrm{O}_{3}{ }^{2-}+2 \mathrm{O}_{2}+\mathrm{H}_{2} \mathrm{O} \leftrightarrow 2 \mathrm{H}^{+}+2 \mathrm{SO}_{4}{ }^{2-}$ & $>7$ & 25 \\
\hline $\mathrm{nS}^{2-}+2(n-1) \mathrm{H}_{2} \mathrm{O} \leftrightarrow \mathrm{S}_{n}^{2-}+2(n-1) \mathrm{OH}^{-}+(n-1) \mathrm{H}_{2}$ & $>7$ & $>70$ \\
\hline $\mathrm{HS}^{-}+2 \mathrm{Fe}^{3+} \leftrightarrow 1 / 8 \mathrm{~S}_{8}+\mathrm{H}^{+}+2 \mathrm{Fe}^{2+}$ & $5-8$ & - \\
\hline $\mathrm{S}_{n}^{2-}+3 / 2 \mathrm{O}_{2} \leftrightarrow \mathrm{S}_{2} \mathrm{O}_{3}{ }^{2-}+[(n-2) / 8] \mathrm{S}_{8}$ & - & - \\
\hline $\mathrm{S}_{3} \mathrm{O}_{6}{ }^{2-}+2 \mathrm{OH}^{-} \leftrightarrow \mathrm{S}_{2} \mathrm{O}_{3}{ }^{2-}+2 \mathrm{H}_{2} \mathrm{O}+\mathrm{SO}_{4}{ }^{2-}$ & $>7$ & - \\
\hline $\mathrm{HS}^{-}+\mathrm{SO}_{3}{ }^{2-}+1 / 2 \mathrm{O}_{2} \leftrightarrow \mathrm{S}_{2} \mathrm{O}_{3}{ }^{2-}+\mathrm{OH}^{-}$ & $5-8$ & - \\
\hline $\mathrm{nHS}^{-}+(n-1) / 2 \mathrm{O}_{2} \leftrightarrow \mathrm{S}_{n}^{2-}+\mathrm{H}_{2} \mathrm{O}+(n-2) \mathrm{OH}^{-}$ & - & - \\
\hline $4 \mathrm{~S}_{4} \mathrm{O}_{6}{ }^{2-}+4 \mathrm{H}_{2} \mathrm{O} \leftrightarrow 6 \mathrm{~S}_{2} \mathrm{O}_{3}{ }^{2-}+\mathrm{S}_{3} \mathrm{O}_{6}{ }^{2-}+\mathrm{SO}_{4}{ }^{2-}+8 \mathrm{H}^{+}$ & $<7$ & $25-70$ \\
\hline $\mathrm{S}_{2} \mathrm{O}_{3}{ }^{2-}+\mathrm{O}_{2} \leftrightarrow \mathrm{SO}_{3}{ }^{2-}+\mathrm{S}_{4} \mathrm{O}_{6}{ }^{2-}$ & $<7$ & 25 \\
\hline $3 \mathrm{~S}_{3} \mathrm{O}_{6}{ }^{2-} \leftrightarrow 2 \mathrm{SO}_{4}{ }^{2-}+\mathrm{S}_{4} \mathrm{O}_{6}{ }^{2-}+1 / 8 \mathrm{~S}_{8}+2 \mathrm{SO}_{2}$ & 4 & 35 \\
\hline $\mathrm{HS}^{-}+2 \mathrm{O}_{2} \leftrightarrow \mathrm{SO}_{4}^{2-}+\mathrm{H}^{+}$ & 8 & 10 \\
\hline
\end{tabular}

Table 2 Kinetic reactions of sulfur-containing compounds considered in this study at $25^{\circ} \mathrm{C}$ (Machel 1987; Moses et al. 1987; Wilkin and Barnes 1996; Zhang and Millero 1991, 1993; Heinen and Lauwers 1996; Lin et al. 2004; Zhao et al. 2007; TengShui et al. 2009; MirandaTrevino et al. 2013)

\begin{tabular}{lll}
\hline Kinetic reaction & Rate coefficient & Rate order \\
\hline $\mathrm{S}_{3} \mathrm{O}_{6}^{2-}+\mathrm{Fe}^{3+}+1 / 2 \mathrm{O}_{2} \rightarrow \mathrm{S}_{2} \mathrm{O}_{3}^{2-}+\mathrm{SO}_{4}^{2-}+\mathrm{Fe}^{2+}$ & $3.2 \times 10^{-2} \mathrm{~s}^{-1}$ & {$\left[\mathrm{~S}_{3} \mathrm{O}_{6}^{2-}\right]$} \\
$4 \mathrm{~S}_{4} \mathrm{O}_{6}^{2-}+6 \mathrm{OH}^{-} \rightarrow 5 \mathrm{~S}_{2} \mathrm{O}_{3}^{2-}+2 \mathrm{~S}_{3} \mathrm{O}_{6}^{2-}+3 \mathrm{H}_{2} \mathrm{O}$ & $6.1 \times 10^{-3} \mathrm{~s}^{-1}$ & {$\left[\mathrm{~S}_{4} \mathrm{O}_{6}^{2-}\right]$} \\
$2 \mathrm{~S}_{4} \mathrm{O}_{6}^{2-}+6 \mathrm{OH}^{-} \rightarrow 3 \mathrm{~S}_{2} \mathrm{O}_{3}^{2-}+2 \mathrm{SO}_{3}^{2-}+3 \mathrm{H}_{2} \mathrm{O}$ & $5.1 \times 10^{-3} \mathrm{M}^{-1} \mathrm{~s}^{-1}$ & {$\left[\mathrm{~S}_{4} \mathrm{O}_{6}^{2-}\right]^{2}$} \\
$\mathrm{H}_{2} \mathrm{~S}+1.5 \mathrm{O}_{2} \rightarrow \mathrm{SO}_{3}^{2-}+2 \mathrm{H}^{+}$ & $k_{1}^{\mathrm{a}}$ & $\left.\left[\mathrm{H}_{2} \mathrm{~S}_{[}\right] \mathrm{O}_{2}\right]$ \\
$\mathrm{SO}_{3}^{2-}+0.5 \mathrm{O}_{2}+\mathrm{H}_{2} \rightarrow \mathrm{SO}_{4}^{2-}+2 \mathrm{H}^{+}$ & $k_{2}^{\mathrm{b}}$ & {$\left[\mathrm{SO}_{3}^{2-}\right]^{2}\left[\mathrm{O}_{2}\right]^{0.5}$} \\
$\mathrm{H}_{2} \mathrm{~S}+\mathrm{SO}_{3}^{2-}+0.5 \mathrm{O}_{2} \rightarrow \mathrm{S}_{2} \mathrm{O}_{3}^{2-}+\mathrm{H}_{2} \mathrm{O}$ & $k_{3}^{\mathrm{c}}$ & $\left.\left[\mathrm{H}_{2} \mathrm{~S}_{[}\right] \mathrm{SO}_{3}^{2-}\right]\left[\mathrm{O}_{2}\right]$ \\
$2 \mathrm{~S}_{2} \mathrm{O}_{3}^{2-}+2 \mathrm{Fe}^{3+} \rightarrow \mathrm{S}_{4} \mathrm{O}_{6}^{2-}+2 \mathrm{Fe}^{2+}$ & $0.66 \mathrm{M}^{-1} \mathrm{~s}^{-1}$ & {$\left[\mathrm{~S}_{2} \mathrm{O}_{3}^{2-}\right]^{2}$} \\
$2 \mathrm{~S}_{2} \mathrm{O}_{3}^{2-}+2 \mathrm{H}^{+}+0.5 \mathrm{O}_{2} \rightarrow \mathrm{S}_{4} \mathrm{O}_{6}^{2-}+\mathrm{H}_{2} \mathrm{O}$ & $1.48 \times 10^{-3} \mathrm{~s}^{-1}$ & {$\left[\mathrm{~S}_{2} \mathrm{O}_{3}^{2-}\right]$} \\
$\mathrm{S}_{3} \mathrm{O}_{6}^{2-}+\mathrm{H}_{2} \mathrm{O} \rightarrow \mathrm{S}_{2} \mathrm{O}_{3}^{2-}+\mathrm{SO}_{4}^{2-}+2 \mathrm{H}^{+}$ & $2.6 \times 10^{-2} \mathrm{~s}^{-1}$ & {$\left[\mathrm{~S}_{3} \mathrm{O}_{6}^{2-}\right]$} \\
$4 \mathrm{~S}_{4} \mathrm{O}_{6}^{2-}+3 \mathrm{Fe}^{3+}+2.75 \mathrm{O}_{2}+4.5 \mathrm{H}_{2} \mathrm{O} \rightarrow 4 \mathrm{SO}_{4}^{2-}+3 \mathrm{Fe}^{2+}+9 \mathrm{H}^{+}$ & $4.4 \times 10^{-2} \mathrm{M}^{-1} \mathrm{~s}^{-1}$ & {$\left[\mathrm{~S}_{4} \mathrm{O}_{6}^{2-}\right]^{2}$} \\
$2 \mathrm{~S}_{4} \mathrm{O}_{6}^{2-} \rightarrow \mathrm{S}_{5} \mathrm{O}_{6}^{2-}+\mathrm{S}_{3} \mathrm{O}_{6}^{2-}$ & $0.4 \times 10^{-2} \mathrm{~s}^{-1}$ & {$\left[\mathrm{~S}_{4} \mathrm{O}_{6}^{2-}\right]$} \\
\hline${ }^{\mathrm{a}} \ln k_{1}=-4.71+0.914 \mathrm{pH}-0.0289 \mathrm{pH}^{2}\left(\mathrm{M}^{-1} \mathrm{~s}^{-1}\right)$ & & \\
${ }^{\mathrm{b}} \ln k_{2}=3.87+1.51 \mathrm{pH}-0.103 \mathrm{pH}^{2}\left(\mathrm{M}^{-1.5} \mathrm{~s}^{-1}\right)$ & & \\
${ }^{\mathrm{c}} \ln k_{3}=-9.01+3.01 \mathrm{pH}-0.177 \mathrm{pH}^{2}\left(\mathrm{M}^{-2} \mathrm{~s}^{-1}\right)$ & &
\end{tabular}

$\mu_{i}=\Gamma_{i}(T)+R T \ln \hat{f}_{i}$

For pure species $i$ in its standard state at the same temperature, this equation reduces to:

$G_{i}^{\circ}=\Gamma_{i}(T)+R T \ln f_{i}^{\circ}$

The difference between these two equations gives:

$\mu_{i}-G_{i}^{\circ}=R T \ln \frac{\hat{f}_{i}}{f_{i}^{\circ}}$

The equilibrium constant for a reaction can be evaluated as follows:

$\Delta G_{r}^{\circ}=-R T \ln K$ where the standard molal Gibbs free energy of the reaction $\left(\Delta G_{r}^{\circ}\right)$ is defined by Eq. (8):

$\Delta G_{r}^{\circ}=\sum_{i} v_{i, r} \Delta G_{i}^{\circ}$

where $P_{c}$ is the stoichiometric coefficient and $\Delta G_{i}^{\circ}$ is the Gibbs free energy of formation for species $i$. Combining Eq. (3) with Eq. (4) and using the definition of equilibrium constant (Eq. 7) result in:

$\prod_{i}\left(\hat{f}_{i} / f_{i}^{\circ}\right)^{v_{i}}=K$

For a reaction occurring in the liquid phase, the fugacity of a species in solution is related to its fugacity $\left(f_{i}\right)$ 
in the pure state at the temperature and pressure of the equilibrium mixture as follows:

$\hat{f}_{i}=\gamma_{i} x_{i} f_{i}$

The activity coefficient $\left(\gamma_{i}\right)$ is determined from Pitzer activity model (Sun et al. 2008). The fugacity ratio in Eq. (9) can now be expressed as:

$\frac{\hat{f}_{i}}{f_{i}^{\circ}}=\frac{\gamma_{i} x_{i} f_{i}}{f_{i}^{\circ}}=\gamma_{i} x_{i}\left(\frac{f_{i}}{f_{i}^{\circ}}\right)$

where this ratio is approximated as:

$\ln \frac{f_{i}}{f_{i}^{\circ}}=\frac{V_{i}\left(P-P^{\circ}\right)}{R T}$

Finally, combining Eqs. (11) and (12) with Eq. (9) yields:

$$
\prod_{i}\left(x_{i} \gamma_{i}\right)^{v_{i}}=K \exp \left[\frac{\left(P^{\circ}-P\right)}{R T} \sum_{i}\left(v_{i} V_{i}\right)\right]
$$

When there are two or more independent chemical reactions in a system, the equilibrium composition can be found by extension of the methods developed for single reactions. In this case, a separate equilibrium constant is evaluated for each reaction $j$ :

$\prod_{i}\left(\hat{f}_{i} / f_{i}^{\circ}\right)^{v_{i, j}}=K_{j}$

Heat capacity and critical data required for the calculation of equilibrium constants of each reaction are obtained from HSC Chemistry 9.0 database (Roine and Anttila 2006). Equilibrium constants are calculated based on the method suggested by Smith et al. (2005). In Eqs. (13) and (14), the mole fractions may be eliminated in favor of the equilibrium value of the reaction coordinate according to Eq. (2). This results in a system of nonlinear algebraic equations where the number of equations needed to be solved is equal to the number of reactions considered in the system.

It should be noted that the purpose of this study is not to mimic reservoir conditions as a function of distance, but rather to observe the effects of composition (and $\mathrm{pH}$ ), temperature, and pressure, on the speciation of the products. The chemistry of sulfur species is studied for a sample seawater-flooded reservoir where hydrogen sulfide is generated microbially in a region close to the injection well. In order to reduce corrosion, oxygen scavengers, such as sulfite and bisulfite, are used in injection waters to react with dissolved oxygen and form sulfate (Eden et al. 1993). However, due to poor deaeration and inadequate scavenger injection, the presence of dissolved oxygen can occur (Maxwell 2006). At high-pressure conditions of downhole reservoirs, the solubility of oxygen in water is nearly proportional to its partial pressure. With the solubility of $3 \mathrm{mg}$ oxygen/L seawater at atmospheric pressure, the solubility should be around 1400-1500 $\mathrm{mg} \mathrm{O}_{2} / \mathrm{L}$ seawater at $30 \mathrm{MPa}$ (Sunde et al. 1992). This provides the required amount of oxidant for the redox reactions to occur. The maximum amount of dissolved iron is directly related to iron sulfide solubility, and based on the approach followed by Verri and Sorbie (2017), it is approximately $0.1 \mathrm{mg} / \mathrm{L}$ for the current case study. Table 3 summarizes the initial conditions used in the model.

\section{Results and discussion}

\section{Sulfur species reactivity and partitioning}

The $K$-values for $\mathrm{H}_{2} \mathrm{~S}$ partitioning between oil, water, and gas phases are first evaluated through equilibrium study and are then included in the reactivity analysis of sulfur species (Burger et al. 2013). The possibility of the formation of a separate solid phase of elemental sulfur is also considered where the amount of elemental sulfur formed in the reacting system is obtained from the reactive model and then based on the solubility of sulfur as a function of temperature and pressure, the amount of sulfur precipitated in the system is calculated (Smith et al. 2005).

In order to study sulfur speciation in the sample seawaterflooded oil reservoir, the initial $\mathrm{pH}$ of the solution at the injection point was varied: Case 1: initial $\mathrm{pH}=5$ (acidic), Case 2: initial $\mathrm{pH}=7$ (neutral), and Case 3: initial $\mathrm{pH}=9$ (basic). The $\mathrm{pH}$ of the solution, as the temperature and pressure change, was also tracked to examine the reactivity/speciation effect on the $\mathrm{pH}$.

Figure 1 shows the results of sulfur speciation analysis as a function of temperature and pressure for initial $\mathrm{pH}$ of 5. It should be noted that in these figures, sulfur species is the summation of the concentration of sulfide, thiosalts, polysulfide ions, sulfate, and sulfite in the aqueous phase. Decreasing temperature and increasing pressure increase

Table 3 Initial and reservoir conditions for studying $\mathrm{H}_{2} \mathrm{~S}$ partitioning behavior (Stemler 2012)

\begin{tabular}{ll}
\hline Pressure $(\mathrm{MPa})$ & $1-35$ \\
Temperature $\left({ }^{\circ} \mathrm{C}\right)$ & $15-85$ \\
Oil API gravity & 34 \\
Gas-oil ratio & 135 \\
Water-cut $(\%)$ & 30 \\
Water production $\left(\mathrm{m}^{3} / \mathrm{d}\right)$ & 20,000 \\
Distance from injection to producer $(\mathrm{m})$ & 600 \\
$\mathrm{H}_{2} \mathrm{~S}($ based on sulfate concentration in seawater concentra- & 869 \\
tion of $2454 \mathrm{mg} / \mathrm{L})(\mathrm{mg} / \mathrm{L})$ & \\
Test separator pressure $(\mathrm{kPa})$ & 690 \\
Test separator temperature $\left({ }^{\circ} \mathrm{C}\right)$ & 65 \\
\hline
\end{tabular}


Fig. 1 The effects of temperature and pressure on sulfur speciation, solid-phase formation, and $\mathrm{H}_{2} \mathrm{~S}$ partitioning, aqueous-phase reactions, initial pH: 5 , a $T: 25^{\circ} \mathrm{C}, \mathbf{b} P: 1 \mathrm{MPa}$, c $T: 75^{\circ} \mathrm{C}, \mathbf{d} P: 25 \mathrm{MPa}$ (sulfur species is the total concentration of sulfate, sulfite, polysulfide ions, and thiosalts)

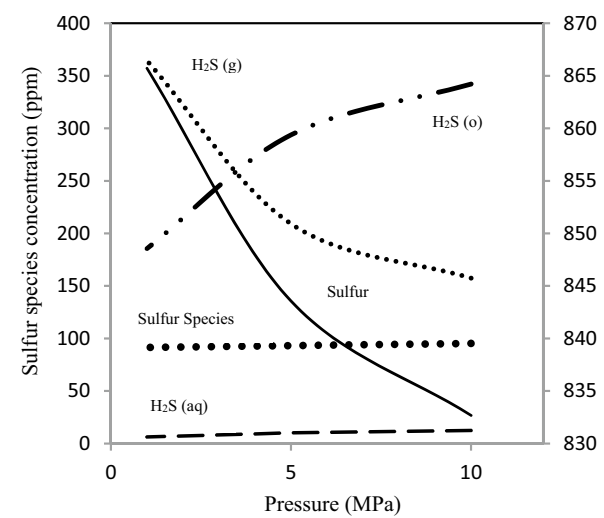

(a)

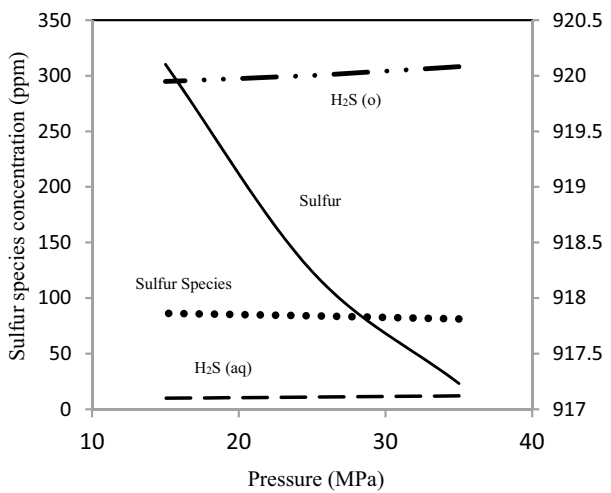

(c)

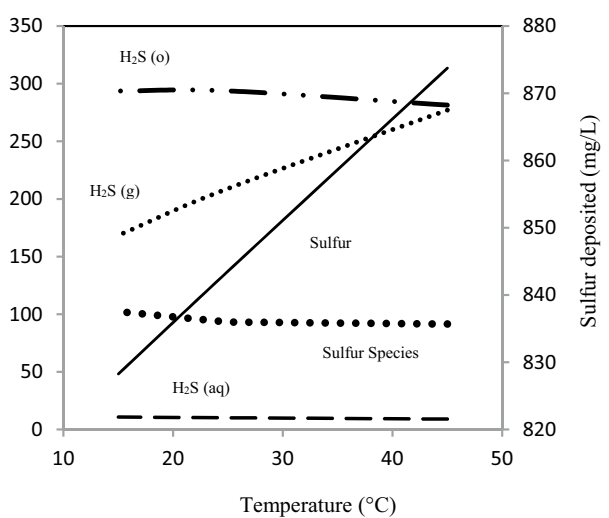

(b)

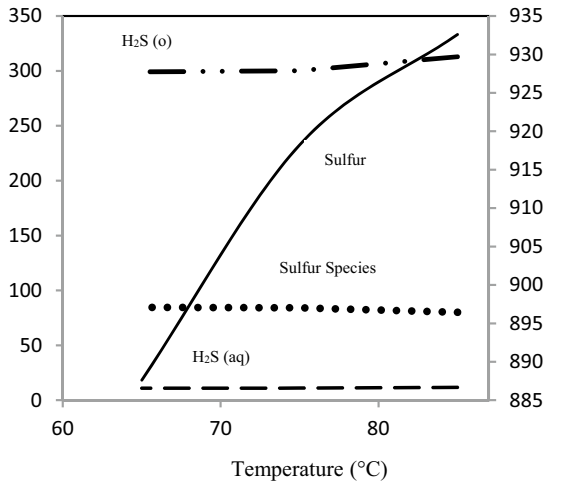

(d) the solubility of sulfur in the aqueous phase. In theory, as the reservoir fluid transfers from reservoir to surface, the temperature and pressure drop and a fraction of total sulfur is converted to elemental sulfur. The solubility of the formed sulfur in the aqueous phase under reservoir conditions is low, and therefore, most of the sulfur forms as a separate solid phase and precipitates. An increase in temperature and a decrease in pressure increase the potential for elemental sulfur formation and, therefore, sulfur deposition. Sulfur solubility in the aqueous phase also decreases with a decrease in temperature. The combination of deposition of sulfur within the reservoir and increased sulfur solubility as the reservoir fluid flows toward topsides, meaning that the amount of elemental sulfur deposited from reservoir to wellhead decreases.

The bubble point pressure of the reservoir fluid was calculated to be approximately $15 \mathrm{MPa}$. Above this pressure, no separate gas phase is evolved and the $\mathrm{H}_{2} \mathrm{~S}$ partitions between oil and water (Fig. 1c, d). $\mathrm{H}_{2} \mathrm{~S}$ solubility in the hydrocarbonrich phase is higher than in the aqueous phase, and therefore, above the bubble point pressure, $\mathrm{H}_{2} \mathrm{~S}$ is concentrated in the oil phase. When pressure is decreased and temperature is increased, a gas phase forms and $\mathrm{H}_{2} \mathrm{~S}$ partial pressure increases in the gas phase (Fig. 1a, b). The amount of $\mathrm{H}_{2} \mathrm{~S}$ in the gas phase from the model at test separator conditions is $487 \mathrm{ppm}$, while the $\mathrm{H}_{2} \mathrm{~S}$ content of oil is $134 \mathrm{ppm}$ and that of water phase is $4 \mathrm{ppm}$. Other sulfur species including thiosalts, polysulfide ions, sulfate, and sulfite constitute $90 \mathrm{ppm}$ of the total sulfur in the aqueous phase. Elemental sulfur in the form of a separate solid phase is also formed at $965 \mathrm{mg} / \mathrm{L}$. The $\mathrm{pH}$ of the solution varied slightly as the chemical reactions occurred. The initial $\mathrm{pH}$ increased from 5 to 5.2 as the pressure and temperature decreased from $35 \mathrm{MPa}$ and $85^{\circ} \mathrm{C}$ to $1 \mathrm{MPa}$ and $15^{\circ} \mathrm{C}$.

Without considering the formation of other sulfur species (i.e., assuming that all the initial sulfate in the injected seawater is converted to $\mathrm{H}_{2} \mathrm{~S}$ and partitions between phases), under test separator conditions, the gas phase would contain $1080 \mathrm{ppm}$, the oil phase contains $235 \mathrm{ppm}$, and water phase contains $7 \mathrm{ppm}_{2} \mathrm{~S}$. This large difference in the composition of produced fluid highlights the importance of studying sulfur speciation when investigating reservoir souring.

The impacts of temperature and pressure on sulfur speciation for Cases 2 and 3 are summarized in Figs. 2 and 3 , respectively. Due to the dissociation of $\mathrm{H}_{2} \mathrm{~S}$ to bisulfide at $\mathrm{pH}$ values near neutral, the amount of molecular $\mathrm{H}_{2} \mathrm{~S}$ in the aqueous phase and, therefore, the amount in oil and gas phases in equilibrium decreases.

As the reservoir fluid flows from reservoir to the surface, and the temperature and pressure decrease, elemental sulfur 
Fig. 2 The effects of temperature and pressure on sulfur speciation, solid-phase formation, and $\mathrm{H}_{2} \mathrm{~S}$ partitioning, aqueous-phase reactions, initial pH: 7, a $T: 25^{\circ} \mathrm{C}, \mathbf{b} P: 1 \mathrm{MPa}$, c $T: 75^{\circ} \mathrm{C}, \mathbf{d} P 25 \mathrm{MPa}$ (sulfur species is the total concentration of sulfate, sulfite, polysulfide ions, and thiosalts)

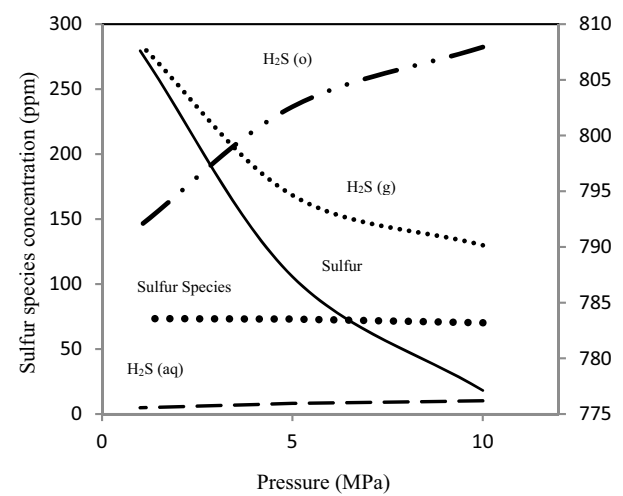

(a)

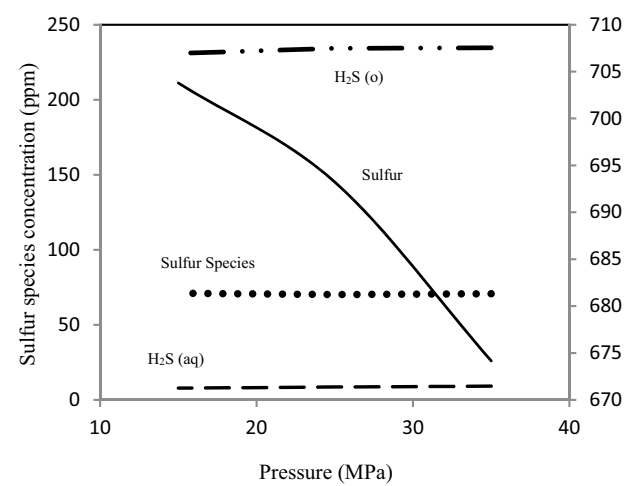

(c)

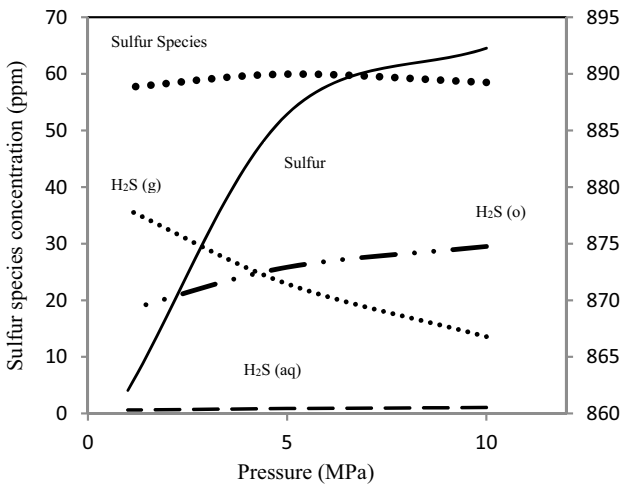

(a)

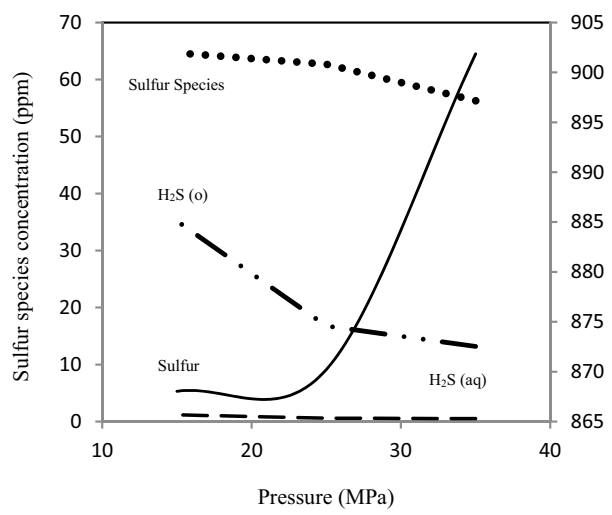

(c)

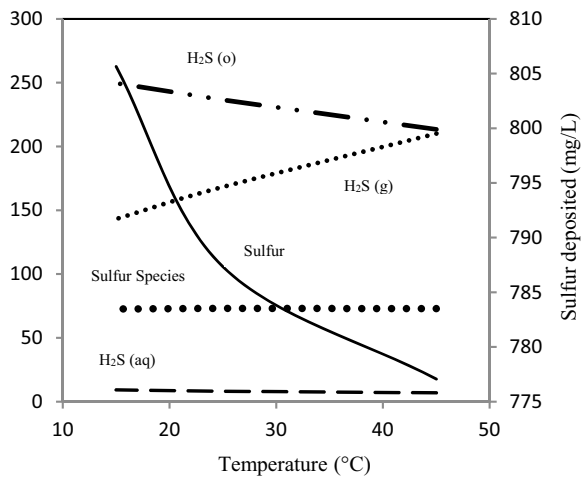

(b)

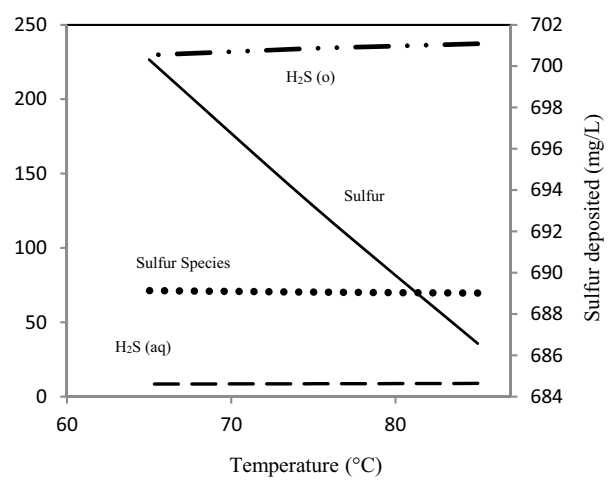

(d)

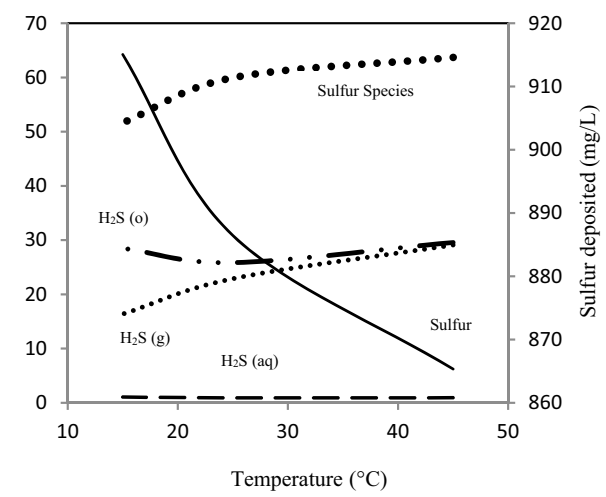

(b)

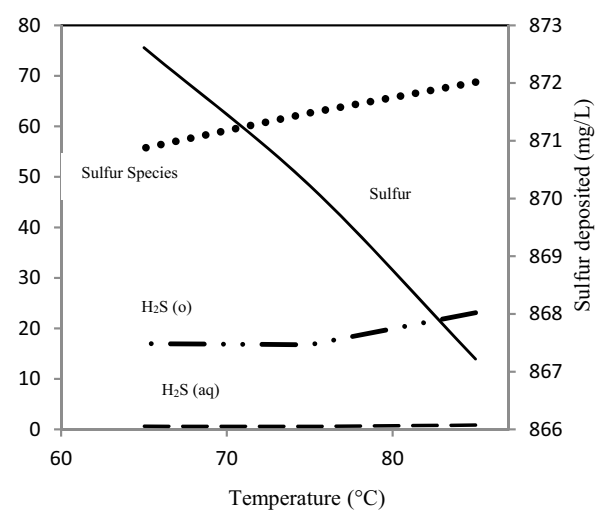

(d) 
forms. As discussed before, the solubility of the elemental sulfur in the aqueous phase decreases with a decrease in temperature and an increase in pressure and therefore, forms as a separate solid phase and precipitates. However, sulfur of oxidation state zero $\left(S^{\circ}\right)$ has low chemical stability at high $\mathrm{pH}$ values and therefore, less elemental sulfur is formed compared to acidic conditions.

At high $\mathrm{pH}$ values, the amount of $\mathrm{H}_{2} \mathrm{~S}$ in the aqueous phase decreases as it dissociates to sulfide and bisulfide resulting in an overall decrease in the $\mathrm{H}_{2} \mathrm{~S}$ content of oil and gas phases. The presence of sulfur species with different valence states influences the amount of molecular $\mathrm{H}_{2} \mathrm{~S}$ in the aqueous phase and, consequently, the amount formed in other phases in equilibrium. At $\mathrm{pH}$ values above $7, \mathrm{H}_{2} \mathrm{~S}$ dissociates to sulfide which could be oxidized to thiosulfate (Chen and Morris 1972) initiating the formation of tetrathionate, polysulfide ions, and elemental sulfur. At these conditions, thiosulfate is converted to sulfide and sulfate (Lin et al. 2004). The $\mathrm{pH}$ of the reacting system decreases from 9 to 8.7 as the pressure and temperature change from $35 \mathrm{MPa}$ and $85{ }^{\circ} \mathrm{C}$ to $1 \mathrm{MPa}$ and $15^{\circ} \mathrm{C}$.

The amount of $\mathrm{H}_{2} \mathrm{~S}$ in the gas phase from the model at test separator conditions is $7 \mathrm{ppm}$, while the $\mathrm{H}_{2} \mathrm{~S}$ content of oil is $2 \mathrm{ppm}$ and that of water phase is $0.06 \mathrm{ppm}$. Other sulfur species including thiosalts, polysulfide ions, sulfate, and sulfite make up $65 \mathrm{ppm}$ of the total sulfur aqueous phase. Elemental sulfur in the form of a separate solid phase is also formed $(845 \mathrm{mg} / \mathrm{L})$.

When the initial $\mathrm{pH}$ of the solution is above neutral conditions (case 3), less polysulfide ions form in the solution, while the amount of sulfate and thiosalts, especially thiosulfate and pentathionate, increase with the $\mathrm{pH} . \mathrm{H}_{2} \mathrm{~S}$ dissociates to sulfide and bisulfide, and therefore, the amount of molecular $\mathrm{H}_{2} \mathrm{~S}$ in the aqueous phase and that in the oil and gas phases decreases. Again, in this case, one might estimate $0.5 \mathrm{ppm} \mathrm{H}_{2} \mathrm{~S}$ in the aqueous phase, $22.5 \mathrm{ppm} \mathrm{H}_{2} \mathrm{~S}$ in the gas phase, and $13.4 \mathrm{ppm}_{2} \mathrm{~S}$ in the oil phase with ignoring sulfur speciation which leads to over prediction of $\mathrm{H}_{2} \mathrm{~S}$ in the reservoir fluid.

Figure 4 illustrates sulfur speciation as a function of $\mathrm{pH}$ of the environment. Sulfur speciation is significantly influenced by the $\mathrm{pH}$ of the solution. Increasing the $\mathrm{pH}$ from acidic to basic is accompanied with the formation of polysulfides. At low $\mathrm{pH}$ values, $\mathrm{H}_{2} \mathrm{~S}$ exists in the molecular form and partitions between oil, water, and gas phases below bubble point pressure. As $\mathrm{pH}$ increases, $\mathrm{H}_{2} \mathrm{~S}$ dissociates to sulfide and bisulfide resulting in the decrease in the $\mathrm{H}_{2} \mathrm{~S}$ content of all phases at equilibrium.

Table 4 summarizes the results of sulfur speciation for the three cases. These results are compared to the base case study where no sulfur speciation is considered and all the sulfur is in the form of $\mathrm{H}_{2} \mathrm{~S}$.

\section{Model evaluation}

The results of the sulfur speciation obtained in this study were compared with experimental data for a sample produced water generated in offshore oil production (Witter and Jones 1998). Sulfide, polysulfide ions, thiosulfate, sulfite, and sulfate were measured in the produced water sample. Elemental sulfur and polythionates were not considered. However, it was indicated that elemental sulfur is present in the produced water sample in low concentrations (Witter and Jones 1998). More than 39\% of the measured inorganic sulfur compounds were sulfide ( $\mathrm{HS}^{-}$and $\mathrm{S}^{2-}$ ) making it the second most abundant species after sulfate (56\% of the total inorganic sulfur compounds). Polysulfide ions and thiosulfate formed $3 \%$ and $2 \%$ of the measured sulfur species, respectively. Sulfite accounted for less than $1 \%$ of sulfur in the produced water.

According to the proposed model, at atmospheric temperature and pressure and under basic conditions (similar to the conditions in the study of Witter and Jones 1998), sulfate and thiosalts constitute $58 \%$ and $23 \%$ of the total
Fig. 4 The effect of $\mathrm{pH}$ on sulfur speciation, solid-phase formation, and $\mathrm{H}_{2} \mathrm{~S}$ partitioning, aqueous-phase reactions, $\mathbf{a} T$ : $25^{\circ} \mathrm{C}, P: 1 \mathrm{MPa}, \mathbf{b} T: 75^{\circ} \mathrm{C}, P$ : $25 \mathrm{MPa}$ (sulfur species is the total concentration of sulfate, sulfite, polysulfide ions, and thiosalts)

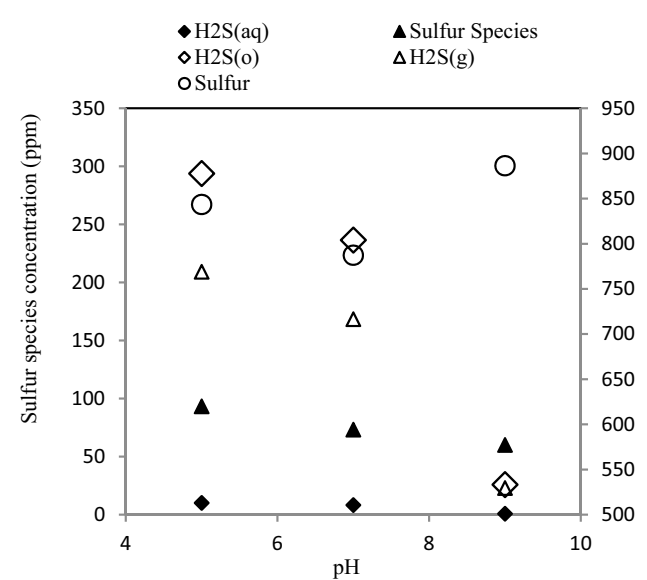

(a)

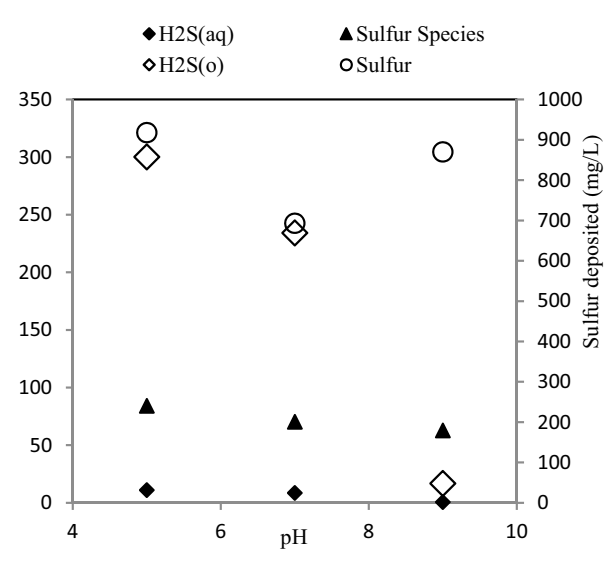

(b) 
Table 4 Comparison of the results of sulfur speciation for three cases at $T: 15^{\circ} \mathrm{C}, P$ : $1 \mathrm{MPa}$

\begin{tabular}{|c|c|c|c|c|c|c|c|}
\hline \multirow[t]{2}{*}{$\mathrm{pH}$} & \multicolumn{6}{|c|}{ Sulfur compounds concentration (ppm) } & \multirow{2}{*}{$\begin{array}{l}\text { Sulfur } \\
\text { deposited } \\
(\mathrm{mg} / \mathrm{L})\end{array}$} \\
\hline & Polysulfides $^{\mathrm{a}}$ & Sulfate & Thiosalts $^{\mathrm{b}}$ & $\mathrm{H}_{2} \mathrm{~S}(\mathrm{aq})$ & $\mathrm{H}_{2} \mathrm{~S}(\mathrm{~g})$ & $\overline{\mathrm{H}_{2} \mathrm{~S}(\mathrm{o})}$ & \\
\hline 5 & 38.5 & 48.7 & 7.3 & 6 & 272.4 & 201.3 & 831 \\
\hline 7 & 22.7 & 60.8 & 16 & 5.29 & 240.4 & 177.3 & 835 \\
\hline 9 & 11.8 & 104.2 & 32.3 & 0.06 & 2.6 & 1.6 & 868 \\
\hline Base case ${ }^{c}$ & - & - & - & 12.5 & 567.5 & 420 & - \\
\hline
\end{tabular}

a Polysulfide ions is the summation of $\mathrm{S}_{2}{ }^{2-}, \mathrm{S}_{3}{ }^{2-}, \mathrm{S}_{4}{ }^{2-}, \mathrm{S}_{5}{ }^{2-}$

${ }^{\mathrm{b}}$ Thiosalts is the summation of $\mathrm{S}_{2} \mathrm{O}_{3}{ }^{2-}, \mathrm{S}_{3} \mathrm{O}_{6}{ }^{2-}, \mathrm{S}_{4} \mathrm{O}_{6}{ }^{2-}, \mathrm{S}_{5} \mathrm{O}_{6}{ }^{2-}$

${ }^{\mathrm{c}} \mathrm{Base}$ case: all the initial sulfate forms $\mathrm{H}_{2} \mathrm{~S}$, initial $\mathrm{pH}$ : 5
Table 5 Sulfur speciation at $25^{\circ} \mathrm{C}$ and $101 \mathrm{kPa}, \mathrm{pH}=9$

\begin{tabular}{lllll}
\hline & \multicolumn{3}{l}{ Sulfur content of aqueous phase (\%) } \\
\cline { 2 - 5 } & Sulfate & Thiosulfate & Polysulfides $^{\mathrm{a}}$ & $\mathrm{HS}^{-}, \mathrm{S}^{2-}$ \\
\hline $\begin{array}{l}\text { Experimental value } \\
\text { (Witter and Jones }\end{array}$ & 56 & 2 & 3 & 39 \\
$\begin{array}{l}\text { 1998) } \\
\text { Model results }\end{array}$ & 58 & 1.8 & 3.7 & 31 \\
\hline
\end{tabular}

${ }^{\text {a }}$ Polysulfide ions are the summation of $\mathrm{S}_{2}{ }^{2-}, \mathrm{S}_{3}{ }^{2-}, \mathrm{S}_{4}{ }^{2-}, \mathrm{S}_{5}{ }^{2-}$

sulfur, respectively. Pentathionate accounted for $17 \%$ of the total thiosalts. Thiosulfate, trithionate, and tetrathionate constitute $1.8 \%, 1.5 \%$, and $2.7 \%$ of the total sulfur, respectively. Approximately, $4 \%$ of the total sulfur was polysulfide ions $\left(\mathrm{S}_{2}{ }^{2-}, \mathrm{S}_{3}{ }^{2-}, \mathrm{S}_{4}{ }^{2-}\right.$, and $\left.\mathrm{S}_{5}{ }^{2-}\right)$. At high $\mathrm{pH}$ values, hydrogen sulfide dissociates to sulfide and bisulfide making up approximately $12 \%$ of the total sulfur in the reacting system. Elemental sulfur deposition was $880 \mathrm{mg} / \mathrm{L}$ or less than $3 \%$ of the total sulfur in the aqueous phase.

Table 5 summarizes the results of reactivity analysis in this study compared to the experimental data by Witter and Jones for a sample produced water. There is a good agreement between the model predictions and the experimental data. However, no experimental data on intermediate sulfur species such as polythionates were reported. This could partially explain the difference in the concentration of sulfide and polysulfides in the proposed model and the experimental data. Furthermore, the values of first and second dissociation constants of $\mathrm{H}_{2} \mathrm{~S}$ in water were obtained from various references (Sun et al. 2008). There is no consistent data for these values in the literature and this could result in some error in the calculation of the final composition of the produced fluid.

This study contributes toward predicting sulfur chemistry in soured reservoirs as it examined the reactivity, partitioning behavior and therefore, relative impact of different sulfur species on $\mathrm{H}_{2} \mathrm{~S}$ partitioning behavior and finally, on reservoir souring, and therefore, enables one estimating the quality of the produced fluid as a result of seawater injection for enhancing oil recovery.

\section{Conclusions}

A new approach was followed in this study for studying sulfur chemistry in reservoirs undergoing seawater injection in an attempt to fill the gap in addressing reservoir souringrelated issues in offshore operations. Most souring models and management plans do not include sulfur speciation and consider only microbially conversion of the initial sulfate in the injected seawater to $\mathrm{H}_{2} \mathrm{~S}$. This results in the potential for over prediction of $\mathrm{H}_{2} \mathrm{~S}$ in the reservoir fluids. For instance in this study, the gas phase under test separator conditions on the surface would contain $1080 \mathrm{ppm}_{2} \mathrm{~S}$, the oil phase contains $235 \mathrm{ppm}_{2} \mathrm{~S}$, and water phase contains $7 \mathrm{ppm}_{2} \mathrm{~S}$ without including sulfur chemistry. At low $\mathrm{pH}$ values, sulfate, polysulfide ions, and hydrogen sulfide are dominant in the solution. Less than $10 \%$ of the total sulfur is formed as thiosalts, predominantly as thiosulfate and pentathionate. Part of the total sulfur is present as elemental sulfur. The solubility of the formed sulfur in the aqueous phase, in the range of temperature and pressure considered in this study, is not high, and therefore, it precipitates as the fluid moves to top surface such that approximately $960 \mathrm{mg} / \mathrm{L}$ solid sulfur is deposited at the producer $\left(15 \mathrm{MPa}, 65^{\circ} \mathrm{C}\right)$. Using the developed reactive model for predicting the partitioning behavior of sulfur species, under test separator conditions, a gas phase containing 487 ppm $\mathrm{H}_{2} \mathrm{~S}$ forms, while the $\mathrm{H}_{2} \mathrm{~S}$ content of oil and water phases in equilibrium is $134 \mathrm{ppm}$ and $4 \mathrm{ppm}$, respectively. When the $\mathrm{pH}$ of the solution is above neutral, most of the total sulfur is found as sulfate and thiosalts. Hydrogen sulfide dissociates to sulfide and bisulfide and less than $10 \%$ polysulfide ions forms. The amount of sulfur deposited as elemental sulfur is slightly decreased from $965 \mathrm{mg} / \mathrm{L}$ at low $\mathrm{pH}$ values to less than $844 \mathrm{mg} / \mathrm{L}$ at higher $\mathrm{pH}$ values. In addition, at high $\mathrm{pH}$ values, the amount of molecular $\mathrm{H}_{2} \mathrm{~S}$ which partitions between phases is decreased significantly. The sulfur reactivity results in the formation 
of $7 \mathrm{ppm} \mathrm{H}_{2} \mathrm{~S}$ in the gas phase, $2 \mathrm{ppm}$ in the oil phase, and $0.06 \mathrm{ppm}$ in the water phase.

If sulfur speciation is not considered in determining the extent of reservoir souring, souring mitigation methods could lead to over-treating a reservoir. It also impacts the effectiveness of the produced water treatment systems. Considering the limited space for equipment to treat or mitigate souring on offshore platforms, these issues represent a cost and logistical problem. Current reservoir models oversimplify the complex sulfur chemistry, and developing effective souring control method requires the complete picture. Therefore, the major contribution of this study is identifying the key chemical compounds, reaction schemes, and developing a methodology to incorporate into a more comprehensive reservoir simulator, to model transport and transformation in reservoirs soured via seawater injection.

Acknowledgements This work was made possible by the financial and technical support provided by Terra Nova and MITACS.

Open Access This article is licensed under a Creative Commons Attribution 4.0 International License, which permits use, sharing, adaptation, distribution and reproduction in any medium or format, as long as you give appropriate credit to the original author(s) and the source, provide a link to the Creative Commons licence, and indicate if changes were made. The images or other third party material in this article are included in the article's Creative Commons licence, unless indicated otherwise in a credit line to the material. If material is not included in the article's Creative Commons licence and your intended use is not permitted by statutory regulation or exceeds the permitted use, you will need to obtain permission directly from the copyright holder. To view a copy of this licence, visit http://creativecommons.org/licenses/by/4.0/.

\section{References}

Antonio MR, Karet GB, Guzowski JP Jr (2000) Iron chemistry in petroleum production. Fuel 79:37

Berk W, Fu Y, Schulz HM (2015) Temporal and spatial development of scaling in reservoir aquifers triggered by seawater injection: threedimensional reactive mass transport modeling of water-rock-gas interactions. J Pet Sci Eng 135:206

Boulegue J, Lord CJ, Church T (1981) Sulfur speciation and associated trace metals $(\mathrm{Fe}, \mathrm{Cu})$ in the pore waters of Great Marsh, Delaware. Geochim Cosmochim Acta 46:453

Burger ED, Jenneman GE, Caroll JJ (2013) On the partitioning of hydrogen sulfide in oilfield systems. SPE 164067

Chen KY, Morris JC (1972) Kinetics of oxidation of aqueous sulfide by oxygen. Environ Sci Technol 6:529

Druschel GK, Schoonen MAA, Nordstrom K, Ball JW, Xu Y, Cohn CA (2003) Sulfur geochemistry of hydrothermal waters in Yellowstone National Park, Wyoming, USA. III. An anion-exchange resin technique for sampling and preservation of sulfoxyanions in natural waters. Geochem Trans 4:12

Eden B, Laycock PJ, Fielder M (1993) Oilfiled reservoir souring. Offshore Technology Report, OTH 92385

Froment GF, Bischoff KB, De Wilde J (eds) (2009) Chemical reactor analysis and design, 3rd edn. Wiley, New York

Garcia CL, Becchi M, Grenier-Loustalot MF, Paisse O, Szymanski R (2002) Analysis of aromatic sulfur compounds in gas oils using
GC with sulfur chemiluminescence detection and high-resolution MS. Anal Chem 74:3849

Gramp JP, Bigham JM, Jones FS, Tuovinen OH (2010) Formation of Fe-sulfides in cultures of sulfate-reducing bacteria. J Hazard Mater 175:1062

Heinen W, Lauwers AM (1996) Organic sulfur compounds resulting from the interaction of iron sulfide, hydrogen sulfide and carbon dioxide in an anaerobic aqueous environment. Orig Life Evol Biosph 26:131

Lewis AE (2010) Review of metal sulfide precipitation. Hydrometallurgy 104:222

Lin H, Li Z, Tohji K, Tsuchiya N, Yamasaki N (2004) Reaction of sulfur with water under hydrothermal conditions. In: 14th International conference on the properties of water and steam

Machel HG (1987) Some aspects of diagenetic sulphate-hydrocarbon redox reactions. Geol Soc Lond 36:15

Maxwell S (2006) Predicting microbially influenced corrosion (MIC) in seawater injection systems. SPE 100519

Miranda-Trevino JC (2013) The importance of thiosalt speciation in the management of tailing ponds. PhD thesis, Memorial University of Newfoundland (2013)

Miranda-Trevino JC, Pappoe M, Hawboldt K, Bottaro C (2013) The importance of thiosalts speciation: review of analytical methods, kinetics, and treatment. Crit Rev Environ Sci Technol 43:2013

Moses CO, Nordstorm DK, Herman JS, Mills AL (1987) Aqueous pyrite oxidation by dissolved oxygen and by ferric iron. Geochim Cosmochim Acta 51:1561

Pomerantz AE, Seifert DJ, Bake KD, Craddock PR, Mullins OC, Kodalen BG, Mitra-Kirtley S, Bolin TB (2013) Sulfur chemistry of asphaltenes from a highly compositionally graded oil column. Energy Fuels 27:4604

Putra W, Hakiki F (2019) Microbial enhanced oil recovery: interfacial tension and biosurfactant-bacteria growth. J Pet Explor Prod Technol 9:2353

Roine A, Anttila K (2006) HSC chemistry (Version 9.0). http://www. outotec.com/products/digital-solutions/hsc-chemistry/

Smith JM, Van Ness HC, Van Abbott MM (2005) Introduction to chemical engineering thermodynamics, 7 th edn. McGraw-Hill, New York

Steefel CI, DePaolo DJ, Lichtner PC (2005) Reactive transport modeling: an essential tool and a new research approach for the Earth sciences. Earth Planet Sci Lett 240:539

Stemler P (2012) Subsurface control of $\mathrm{H}_{2} \mathrm{~S}$ with nitrate, nitrite and $\mathrm{H}_{2} \mathrm{~S}$ scavenger. Suncor Energy, E \& P East Coast, Terra Nova

Steudel R (1996) Mechanism for the formation of elemental sulfur from aqueous sulfide in chemical and microbiological desulfurization processes. Ind Eng Chem Res 35:1417

Sun W, Nesic S, Young D, Woollam RC (2008) Equilibrium expressions related to the solubility of the sour corrosion product mackinawite. Ind Eng Chem Res 45:1738

Sunde E, Beeder J, Nilsen RK, Torsvik T (1992) Aerobic microbial enhanced oil recovery for offshore use. SPE/DOE 24204

Tang K, Baskaran V, Nemati M (2009) Bacteria of the sulphur cycle: an overview of microbiology, biokinetics and their role in petroleum and mining industries. Biochem Eng J 44:73

TengShui C, Qin H, Hong L, PingAn P, Zhong LJ (2009) Thermal simulation experiments of saturated hydrocarbons with calcium sulfate and element sulfur: implications on origin of $\mathrm{H}_{2} \mathrm{~S}$. Sci China Ser D Earth Sci 52:1550-1558

Verri G, Sorbie KS (2017) Iron sources in sour wells: reservoir fluids or corrosion? In: Corrosion conference and expo, Paper No. 8998

Veshareh MJ, Ayatollahi S (2019) Microorganisms' efect on the wettability of carbonate oil-wet surfaces: implications for MEOR, smart water injection and reservoir souring mitigation

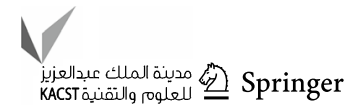


strategies. J Pet Explor Prod Technol. https://doi.org/10.1007/ s13202-019-00775-6

Wilkin RT, Barnes HL (1996) Pyrite formation by reactions of iron monosulfides with dissolved inorganic and organic sulfur species. Geochim Cosmochim Acta 60:4167

Witter AE, Jones AD (1998) Comparison of methods for inorganic sulfur speciation in a petroleum production effluent. Environ Toxicol Chem 17:2176

Xu Y, Schoonen MAA (1995) The stability of thiosulfate in the presence of pyrite in low-temperature aqueous solutions. Geochim Cosmochim Acta 59:4605

$\mathrm{Xu}$ Y, Schoonen MAA, Nordstrom DK, Cunningham KM, Ball JW (2000) Sulfur geochemistry of hydrothermal waters in Yellowstone National Park, Wyoming, USA. II. Formation and decomposition of thiosulfate and polythionate in Cinder Pool. J Volcanol Geoth Res 97:407

Yeh GT, Tripathy VS (1989) A critical evaluation of recent developments in hydrogeochemical transport models of reactive multichemical components. Water Resour Res 25:93

Yeh GT, Siegel MD, Li MH (2001) Numerical modeling of coupled fluid flows and reactive transport including fast and slow chemical reactions. J Contam Hydrol 47:379
Yu B, Xu P, Shi Q, Ma C (2006) Deep desulfurization of diesel oil and crude oils by a newly isolated Rhodococcus erythropolis strain. Appl Environ Microbiol 72:54

Zhang H, Jeffrey MI (2010) A kinetic study of rearrangement and degradation reactions of tetrathionate and trithionate in near-neutral solutions. Inorg Chem 49:10273

Zhang JZ, Millero FJ (1991) The rate of sulfite oxidation in seawater. Geochim Cosmochim Acta 55:677

Zhang JZ, Millero FJ (1993) The products from the oxidation of $\mathrm{H}_{2} \mathrm{~S}$ in seawater. Geochimica et Cosmochimica Acts 57:1705

Zhao GB, John S, Zhang JJ, Hamann JC, Muknahallipatna SS, Legowski S, Ackerman JF, Argyle MD (2007) Production of hydrogen and sulfur from hydrogen sulfide in a nonthermalplasma pulsed corona discharge reactor. Chem Eng Sci 62:2216

Publisher's Note Springer Nature remains neutral with regard to jurisdictional claims in published maps and institutional affiliations. 